\title{
Analyses of land use and land cover change dynamics using GIS and remote sensing during 1984 and 2015 in the Beressa Watershed Northern Central Highland of Ethiopia
}

\author{
Tesfa Worku Meshesha $^{1}$ S. K. Tripathi ${ }^{1} \cdot$ Deepak Khare $^{1}$
}

Received: 18 August 2016/Accepted: 27 September 2016/Published online: 3 October 2016

(C) Springer International Publishing Switzerland 2016

\begin{abstract}
Analysing the trend of land use/land cover change and its cause and consequence on human livelihoods as well as on the environment is a matter of concern for sustainable development and management of natural resource. Retrospective analysis of land use/land cover dynamics and its driving force has been undertaken using satellite images of Landsat5 TM 1984, Landsat5 TM 1999, and Landsat8 TM 2015 with $30 \mathrm{~m}$ spacial resolution for Beressa watershed of Ethiopia. ArcGIS10.2.2 and ERDAS Imagine 14 have been used for image processing to produce 6 land uses/land cover classes in the study area. The result of classified image indicated that in the last 3 decades, farm land and settlement area increased @ 71.6 ha/year and 16.8 ha/year respectively. Between 1984 and 1999, forest cover and water body decreased @ 5 ha/year and 0.03 ha/ year respectively but increased @ 15.6 ha/year and 7.1 ha/ year between 1999 and 2015 respectively. This increase could be possible due to the involvement of local communities to plant trees around their homestead and farm lands. In this program, plantation of indigenous tree species other than eucalyptus (which affect the ecology) was encouraged. The $\%$ share of grazing land and barren land has been decreased to 10 and $10.1 \%$ respectively during 1999 that further reduced to 6.1 and $5.2 \%$ during 2015 as against the 12.4 and $13.1 \%$ during 1984 respectively in the Beressa watershed. Rapid population growth demanded more land for cultivation, more trees for domestic fuelwood consumption and more area for settlement had been
\end{abstract}

Tesfa Worku Meshesha

hopee2011@gmail.com

1 Department of Water Resources Development and Management, Indian Institute of Technology Roorkee, Roorkee, UA 247667, India responsible for drastic change in the land use/land cover change in the last 3 decades in the Beressa watershed. In order to check the loss of area from gazing land and barren land, alternative source income opportunities to the community dwellers may be provided. Therefore, environmental conservation, management and rehabilitation require integrated approach of community development at various levels.

Keywords LULC dynamics - Image processing · Environmental conservation - Arcgis and ERDAS imagine $\cdot$ Ethiopia

\section{Introduction}

Land cover dynamic has the global concern of the twentyfirst century, with the dramatic implication for human survival. Land cover change is the change in the physical as well as biological characteristics of land which is attributable to management including conversion of grazing and forest land into farming land, pollution and land degradation, removal of vegetation, and conversion to nonagricultural uses (Quentin et al. 2006; Prakasam 2010; Shiferaw 2011). Recently research on land use and land cover change detection has drawn attention of many researchers (Liang et al. 2002; Ayele et al. 2016). It affects biodiversity, hydrological cycle, land productivity and the sustainability of natural environment (Lupo et al. 2001). Continuous from the previous and in the coming years land use dynamics has been playing a wide role of driving force in alteration of the global environment (Baulies and Szejwach 1998).

The increasing change is alarming, and can have a huge implication on local, regional, national and global 
environment and consequently affect the food availability (Minale 2013). According to Reid et al. (2000), land use and land cover is continuously changing the surface of the earth. In the past few decades the conversion of forest and wood land, grass and pasture land into agricultural and pasture land has dramatically increasing in the tropics (Turner 1990). According to Reid et al. (2000), land cover change is accelerated by human activities and natural processes. Similarly, the change due to the complex interaction of various social, economic and biophysical situations following agricultural diversification, advancement in technology coupled with alarming rate of population pressure.

Minale and Rao (2011) and Shiferaw (2011), pointed out that associated population pressure found to be negative result on land use change. Soil erosion, land degradation, destruction of habitat and biodiversity; loss of endemic species due to you to out migration are resulted from land use dynamics (Meyer and Turner 1992). Even though many controversies on the factors of land cover dynamics, few research studies concluded that demographic factor is intensively accelerate to land use cover change (Mather and Needle 2000). Alarming rate of population dynamics, insecure land use right, lack of credit facilities and lack of market availability are some of socio-economic factors which facilitates for the change of land cover. For the poor those are living under subsistence farming has no other option other than natural resource. There was mismanagement of natural resource such as overgrazing, de-vegetation and expansion of agriculture into the marginal land as well as steep slope for the survival of their livelihoods (Grepperud 1996; Minale and Rao 2012a, b; Amare 2013; Asres et al. 2016). Despite the expansion of cultivation from sloping into steeper slope with inappropriate soil and water conservation measure, crop production is still lagging behind by $2.67 \%$ annual population growth rate (Asres et al. 2016). Intense pressure on agricultural land, forest land and the availability of fuelwood in the sounding area in Ethiopia is the result of spatial and demographic changes; it exerts massive pressure on land use, agricultural productivity, and the use of ecosystem (Minale and Rao 2011).

In most parts of the world, particularly in developing countries agriculture is the livelihoods of the population in turn primarily the most driver of land use change. However, limited studies have been done on long term trend of land cover change (Goldewijk and Ramankutty 2004). For instance, in east Africa in the last 50 years, as the expense of other land use, there has been intensive expansion of agriculture into marginal land (Yitaferu 2007). Semiarid and sub humid areas were dominated by pasture land with widely scattered settlement and agricultural activity before 1950, but then after there has been a massive change of grazing land into mixed crop- livestock agriculture.
Interaction between various socio-economic conditions of the society, population pressure, physiographic feature, and land use type has resulted in land use change, the conceptual framework of which is presented in Fig. 1. Therefore, land use classification used to analyse the interaction between socio-economic and land use, which is contributed for the dynamics of land use and land cover change resulted from diversified and intensified agriculture and livestock population (Mendoza et al. 2002).

The interaction between various anthropogenic and natural factors cause for land cover change (Fasona and Omojola 2005) and the utilization of this resource by human population in time and space (Clevers et al. 2004), analysing land use and land cover change at watershed and sub-watershed level using Landsat imagery and clearly identifying the rate and extent of land cover change is critically important input for the prioritization of natural resource management. To monitor land use and land cover dynamics, geospatial techniques has important role, therefore, geographic information system tools are used to grasp information about extent, rate and magnitude of land use cover change and disseminate accurate information (Carlson and Sánchez-Azofeifa 1999; Guerschman et al. 2003; Dezso et al. 2005).

As FAO (1986) cited in Asres et al. (2016), in the mid1980s, around 27 Mha highland part of Ethiopia was significantly eroded as the same time around 14 Mha was seriously eroded. It concluded that more than 2 Mha of agricultural lands has reached at the point of zero return. Critically analysing the driving force for land cover dynamics of the past trend is important to understand the recent changes and predict for future alteration. A study of land covers dynamics and its driving force in time and space provides favourable foundation for the sustainability of natural resource systems, because it used to reflect the state of watershed. Therefore, land cover change and its driving forces are important for designing policies and strategies for the sustainable natural resource management and use. Even though different studies have under taken about the extent and status of clearing of forest, land cover change and soil erosion in many parts of Ethiopia, poorly documented about land cover dynamics and its driving force. Therefore, the main objective of the study was to identify land use and land cover dynamics and its driving force in the Beressa watershed in the last 31 years.

\section{Materials and methods}

\section{Study area}

The watershed chosen for the present study lies between $39^{\circ} 37^{\prime} \mathrm{E}-39^{\circ} 32^{\prime} \mathrm{E}$ and $9^{\circ} 40^{\prime} \mathrm{N}-9^{\circ} 41^{\prime} \mathrm{N}$. In administrative 


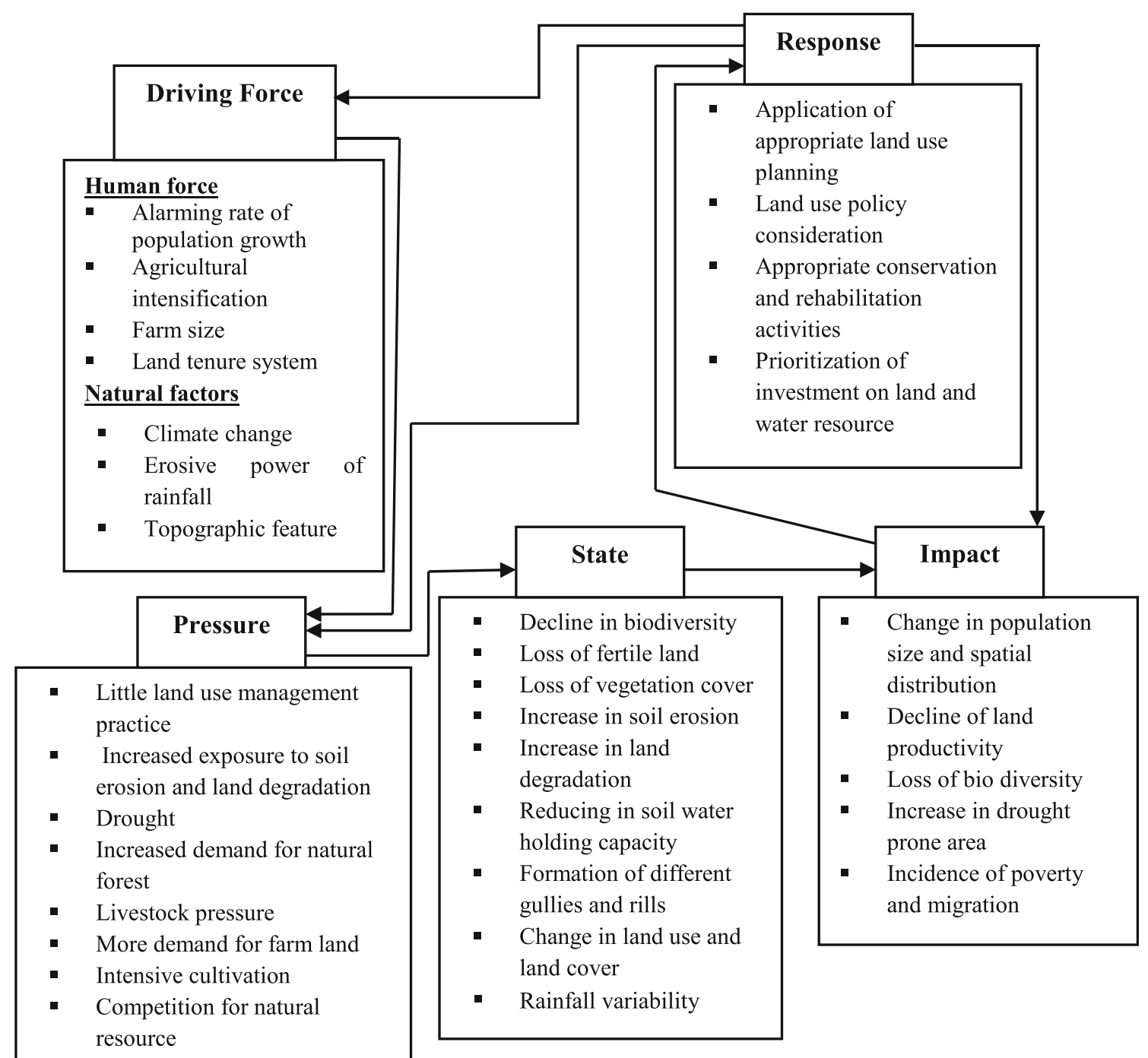

Fig. 1 Conceptual framework on the driving force of land cover change and associated effect. Adopted from FAO 2004; Shiferaw 2011

terms, it is located Basona District, North Showa zone of Amhara regional state. Situated $180 \mathrm{~km}$ distance north east of capital city, Addis Ababa, the watershed forms parts of northern central highlands of Ethiopia which is the parts of Abay basin. The area of the study watershed is $213.2 \mathrm{~km}^{2}$. The watershed is characterized by diverse topographic conditions like mountainous, dissected terrain with steep slope. The elevation ranges from 2200 to $3600 \mathrm{~m}$ a.s.l. The annual average temperature of the area is $19.7^{\circ} \mathrm{C}$; the annual maximum and minimum amount of rainfall is 1083.3 and $698.5 \mathrm{~mm}$ respectively. The most common types of soil are cambisols (locally called Abolse), vertisols (Merere), Andosols, Fluvisols and Regosols. Mixed croplivestock is production system of the area perhaps the only source of livelihoods for the majority of the population. Barely, wheat, horse beans, field peas, lentils and chick peas are commonly growing crops. It is characterized by traditional, rainfed, labor intensive and subsistence oriented or hand to mouth. Cattle and sheep are the dominant types of livestock, but goats, equines, and chickens are also common. Because of rainfall dependent farming practice, farmers are always worried about the duration and intensity of rainfall.

\section{Data source and methods of analysis}

Land cover data The source for land and land cover dynamics was freely downloaded Landsat imagery from http://earthexplore.usgs.gov. The detail of satellite data area presented in Table 1. Landsta5 and landsat8, path/row of $168 / 53$ with $30 \mathrm{~m}$ spatial resolution was acquired on $17 / 12 / 1984,25 / 01 / 1999$, and 23/12/2015. The imagery was processed using ArcGIS10.2.2 and ERDAS IMAGE14 software. Initially images were converted into Universal Transfer Mercator and geo-referenced to a datum in which Ethiopia has selected by WGS-84. To improve the image 
Table 1 Materials and their source used for the study

\begin{tabular}{llllllll}
\hline S. no. & Images & Resolution $(\mathrm{m})$ & Sensor & Path & Row & Date of acquisition & Sources \\
\hline 1 & Landsat5 & $30 \times 30$ & TM & 168 & 53 & $17 / 12 / 1984$ & http://earthexplore.usgs.gov \\
2 & Landsat5 & $30 \times 30$ & TM & 168 & 53 & $25 / 01 / 1999$ & http://earthexplore.usgs.gov \\
3 & Landsat8 & $30 \times 30$ & TM & 168 & 53 & $23 / 12 / 2015$ & http://earthexplore.usgs.gov \\
\hline
\end{tabular}

quality, it was enhanced using histogram equalizations. Then land use and land cover change detection of the study watershed was analysed for the last 31 years. To classify Landsat image supervised classification was used; initially more than 250 signature extractions was used in order to convert images into thematic land cover class.

Before actual identifying the land cover change detection, Thematic Mapper was geo-referenced, transformed and enhanced. To reduce the resolution difference of Thematic Mapper images, using nearest neighbour resampling techniques the image was re-sampled into the same size. The topography of the study area was defined by DEM which is used to describe the elevation of points for the given area at a specific spatial resolution. In addition, sub-basin parameters including slope, slope length, slope width and stream network was obtained from the digital elevation models (DEM). The various steps developed and used to analyse, quantify and interpret the map are presented in Fig. 2.

Lastly six land use and land cover class were identified for the watershed and land use and land cover change were determined in Table 2. To get additional information about the long term experience of land use and land cover change practice in the watershed focus group discussion and informal interview have been conducted. For the discussion and in-depth interview elder peoples were purposively selected as they assumed to have better history of information about the trend of land use and land cover change.

After having classified images, the geographical extent in terms of hectares for land use and land cover class was calculated for each mentioned time periods and the extent of change in land use type within and between time periods was compared. The change of different land use and land cover class has been performed using both ArcGIS10.2.2 and ERDAS IMAGINE14 and finally using the following formula calculation has been employed to know the rate of change hectare/year and percentage share of each class in the studied time periods;

$\Delta \mathrm{A}(\%)=\frac{\mathrm{At} 2-\mathrm{At} 1}{\mathrm{At} 1} \times 100$

where, $\Delta \mathrm{A}(\%)=$ percentage change in the area of land use and land cover class type between initial time $\mathrm{A}_{\mathrm{t} 1}$ and time period $A_{t 2} A_{t 1}=$ area of land use and land cover type at initial time $\mathrm{A}_{\mathrm{t} 2}=$ area of land use and land cover type at final timeAs stated by Abate (2011), the rate of change of land use and land cover type was calculated by the following formula:

$\mathrm{R} \Delta\left(\frac{\mathrm{ha}}{\mathrm{year}}\right) \frac{\mathrm{Z}-\mathrm{X}}{\mathrm{W}}$

where: $\mathrm{R} \Delta=$ rate of change $\mathrm{Z}=$ recent area of land use land cover type in ha $X=$ previous area of land use land cover type in ha $\mathrm{W}=$ time interval between $\mathrm{Z}$ and $\mathrm{X}$ in years.

\section{Result and discussion}

\section{Land use and land cover map}

Red, green and blue band combinations were used to display stacked images in the standard color composite. Spectral class combination to display images frequently varies (Trotter 1998). For the analysis False Color composite bands 2, 3 and 4 used.

In order to meet the requirement of food demand, cultivated land has increased in all parts of the world at the expense of other land use class such as forest, bush/shrubs, barren land and grazing land particularly in developing countries in which majority of inhabitants are depending on agriculture for their survival (Lambin et al. 2003). In the present study similar trend in the watershed has been found where farm land and settlement area have increased over time in all the analysis time periods. Substantial land use change has been observed in the study area since 1970s. To show clearly this substantial change through over time due to various use and the overall change was presented in the year 1984, 1999 and 2015 (Figs. 3a, b, c, 4, 5, 6, 7; Table 3).

\section{Land use and land cover dynamics}

In the present study six classes of land use and land cover were presented namely farm land, barren land, forest land, grazing land, settlement and water body. The land use and land cover dynamics is discussed in the subsequent sections.

Farm land In the study area agriculture occupy the largest share of land cover class $(57.1,61.9$ and $67.5 \%$ in 


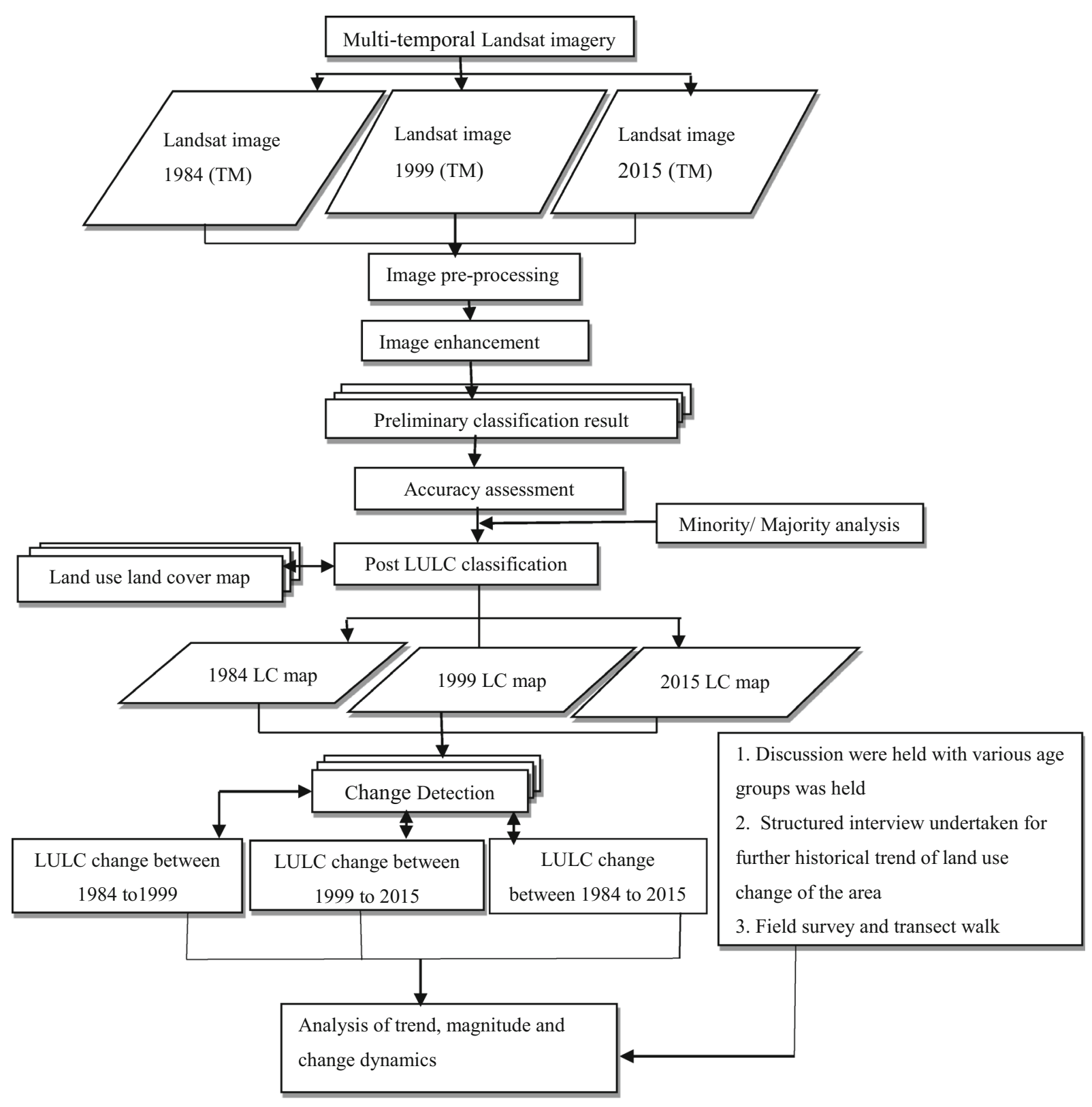

Fig. 2 General methodology for the classification of land use and land cover class

1984, 1999 and 2015 respectively). This implies farm land has been extensively increased at the expense of grazing, barren and forest land. This is due to increased demand because of population growth, additional farm land required to full fill food demand. As a result of extensive expansion of farm land (18.2\%), negatively contributed for the decrease of grazing and barren land by 50.6 and $60.7 \%$ respectively in the last 3 decades (Figs. 3a, b, c, 4, $5,6,7$; Table 3). Due to ever increasing of cultivated land farmers were exert pressure on forest, bushes/shrubs, grazing and barren land and resulted for further accelerate erosion and degradation. Likewise, similar study elsewhere, alarming rate of population growth resulted for the change of land cover class through time (Turner 2009). Similarly, Shiferaw (2011), limited access of off-farm employment opportunity has made the farmers involved clearing of forest and further expanding cultivation into steep slope, grazing land, barren land and other types of land cover class.

Settlement Settlement area in the study watershed has shown increased persistently in the time periods. The total area of the watershed covered by settlement has increased by $24.9 \%$ from 1984 to $1999,28 \%$ from 1999 to 2015 (Figs. 3a, b, c, 4, 5, 6, 7; Table 3). Other than other types of land use systems, the expansion of both rural and urban settlement took the largest share by converting other land 
Table 2 Descriptions of land use land cover class

\begin{tabular}{|c|c|c|}
\hline S. no. & $\begin{array}{l}\text { Land use land cover } \\
\text { class }\end{array}$ & Description \\
\hline 1 & Settlement (ST) & $\begin{array}{l}\text { Scattered rural settlement closely associated with cultivated land and urban settlement. Trees around } \\
\text { homestead mainly eucalyptus are included }\end{array}$ \\
\hline 2 & Farm land (FL) & Land allotted for crop cultivation both annual and perennial crops \\
\hline 3 & Barren land (BL) & $\begin{array}{l}\text { Area with very little or no vegetation cover on the surface of the land. It consists of vulnerable soil to erosion } \\
\text { and degradation. It also includes bedrock which is unable to support cultivation }\end{array}$ \\
\hline 4 & Grazing land (GL) & $\begin{array}{l}\text { Land surface with small grasses in which predominately natural vegetation. It consists of area with scattered } \\
\text { trees used for grazing purpose }\end{array}$ \\
\hline 5 & Water body (WB) & $\begin{array}{l}\text { Is having surface water. It includes pond water, streams, rivers, lakes, marsh land and riverine trees found } \\
\text { along river bank and streams }\end{array}$ \\
\hline 6 & $\begin{array}{l}\text { Forest land and } \\
\text { plantation (FoL) }\end{array}$ & $\begin{array}{l}\text { Area covered with dense natural forest and plantation forest, it includes eucalyptus trees, junipers procera } \\
(\text { Tid }) \text { and mixed indigenous bush and trees species }\end{array}$ \\
\hline
\end{tabular}

use types for instance forest, bushes, and shrubs, barren and grazing land. In the stated time periods (1984-2015) there has been $59.7 \%$ increase of settlement land within the last 31 years. Due to continuous increase of population number they need additional land for settlement area, which costs 520.5 hectare of other land use type.

Grazing land One of the most dominant land cover of the watershed was grazing land it holds $12.4 \%$ of the total land cove types (2633.2 ha) in 1984; however, in 1999 the coverage has been decreased by $2.4 \%$ (from 12.4 to $10 \%$ ). Likewise, in the 2015 the share of grazing land was shrunk to $6.1 \%$ which was double of the decrease in the 1999. Overall in the first periods from 1984 to 1999 the shrinkage of grazing land was reduced by 510.2 ha $(19.4 \%)$; similarly, in the second periods from 1999 to 2015 it has been decreased by 823 ha (38.7 \%) (Figs. 3a, b, c, 4, 5, 6, 7; Table 3). The analysis of land use cover change for 31 years between 1984 and 2015 of this study indicated that 1333.2 ha $(50.6 \%)$ of grazing land has lost. The decrease of gazing land possibly the result of growing demand of more arable land for agricultural cultivation and growing demand for newly formed household for settlement in the watershed. Thus conversion grazing land into farm land and settlement is the common phenomenon practiced in the watershed considered in the present study.

Barren land Barren land within the stated years has shown continuously decreasing trend from $13.1 \%$ in 1984 to $10.1 \%, 5.2 \% 1999$ and 2015 respectively. With alarmingly and intensively declining trends in the first periods from 1984 to 1999 by $23.1 \%$ and further in the second periods from 1999 to 2015 declined by $48.9 \%$. For the last 31 years, about $60.7 \%$ of barren land was changed into other type of land cover classes. This is due to availability of fixed plot of farm land in collaboration with alarming rate of population growth negatively contributed for the decline of barren land.
Forest Land Another most dominant land use cover class of the study catchment was forest resource which ranged densely vegetated trees (natural forest), plantations, shrubs and bushes. The area covered by such forest could be ever green and mixed forest land. From the total area of the catchment in 1984 the share of forest coverage has $12.8 \%$, in contrast the coverage slightly decreased into $12.4 \%$ in the year 1999. As we all know the decrease in forest coverage corresponds to increase population number and extensive expansion of agricultural land. However, in 2015 it has regenerated by $1.2 \%$.

The decrease of forest in the first periods between 1984 and 1999 around by 72.8 ha ( $0.3 \%$ lost), even though too small, given the increase in expansion of agricultural land and increase in population number, it is contradicted from the expectations. However, in the second periods between 1999 and 2015 the share of forest coverage has increased by $4.7 \%$ because the shrinkage of natural forest coverage attributable to regenerated and increased household and community level tree planting. Therefore, over the 31- year time period in between 1984 and 2015 the share has increased by $6.5 \%$. On the basis of local resident response obtained from interview and group discussion, various major reasons have been positively contributed for the increase of share of forest coverage such afforestation, private and community level tree plantation of sesbania susban, tree Lucerne and eucalyptus trees.

It is obviously true that land surface with little vegetative cover exposed to erosion, degradation runoff and insignificant water retention. The increased in runoff caused for intensive sheet erosion and further extend to rills and formation of gullies. The masses of top soil removed from highland to lowland areas, and cause for intense problems for the downstream siltation of ponds and reservoirs, water borne diseases, water pollution, and sediment deposition on fertile farm lands. In many part of the country such problems have already manifested. 
Fig. 3 Land use and land cover map of Beressa watershed. a LULC of Beresa Watershed in 1984. b LULC of Beresa

Watershed in 1999. c LULC of Beresa Watershed in 2015

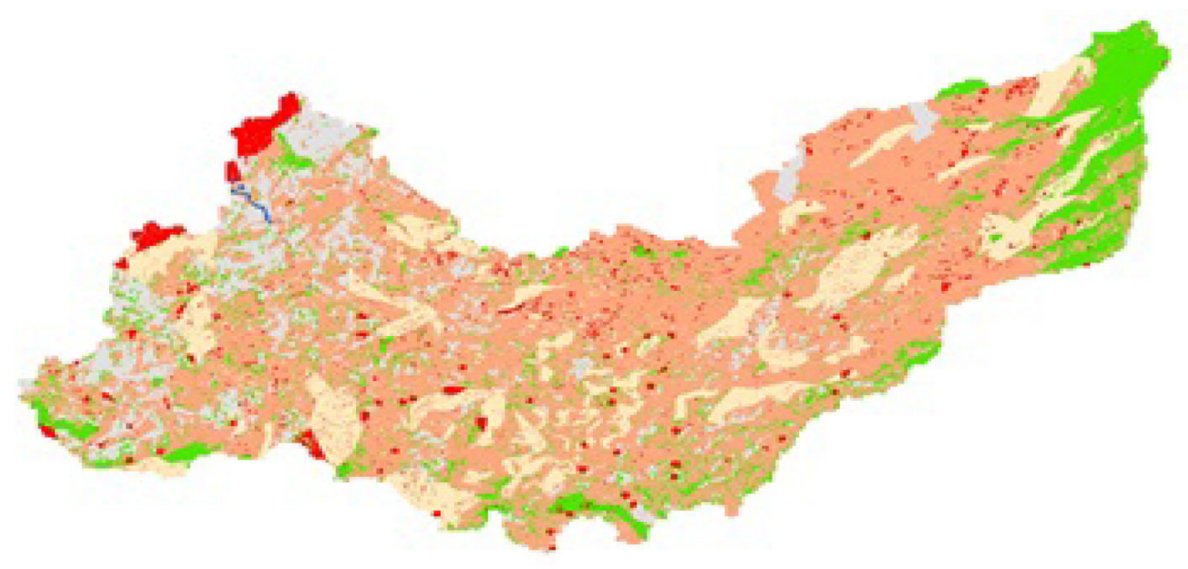

(a) LULC of Beresa Watershed in 1984.

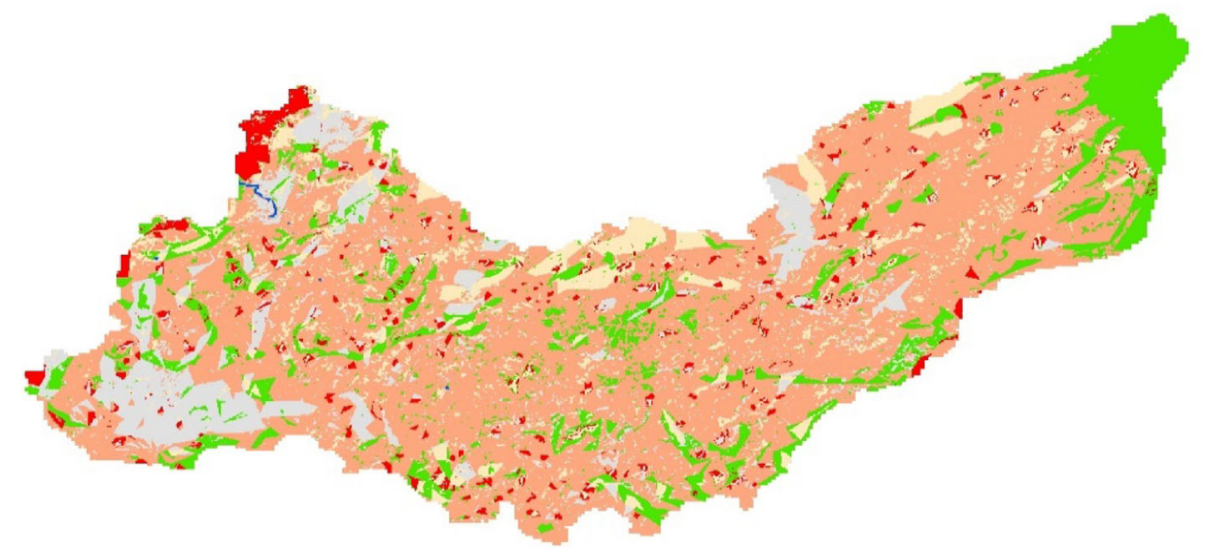

(b) LULC of Beresa Watershed in 1999.

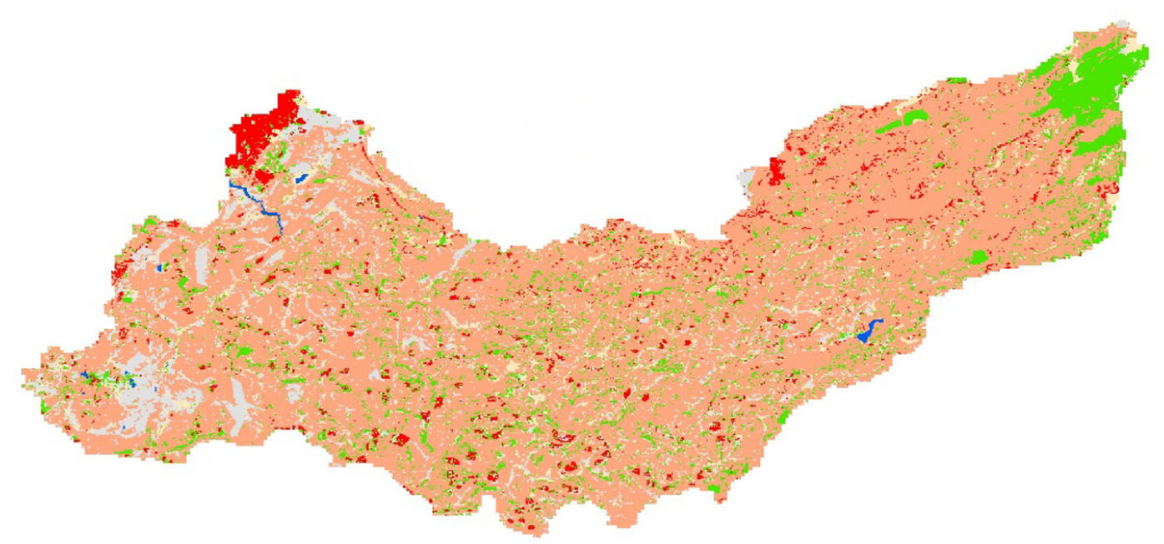

(c) LULC of Beresa Watershed in 2015.

Legend

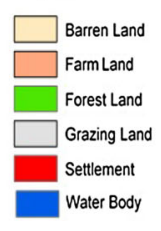


Fig. 4 Land use and land cover types and area coverage of the study watershed in hectare from 1984 to 2015

Fig. 5 Percentage share of land use and land cover class of the study watershed from 1984 to 2015

Fig. 6 Change in Land use and land cover class of the study watershed in hectare from 1984 to 2015
Actual Land use and Land cover class

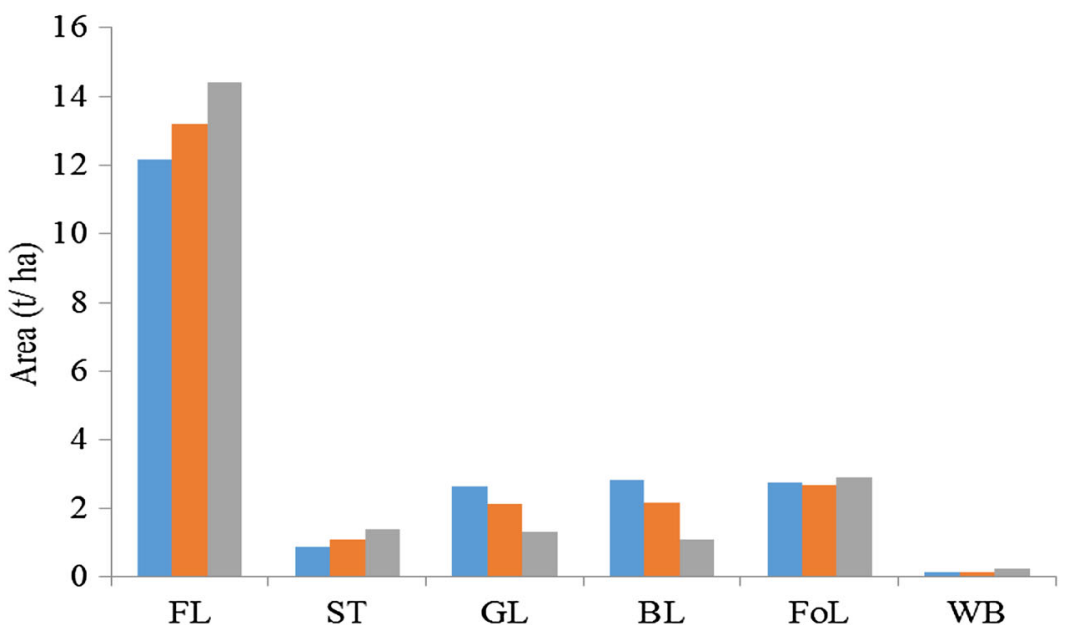

Land use and Land cover class

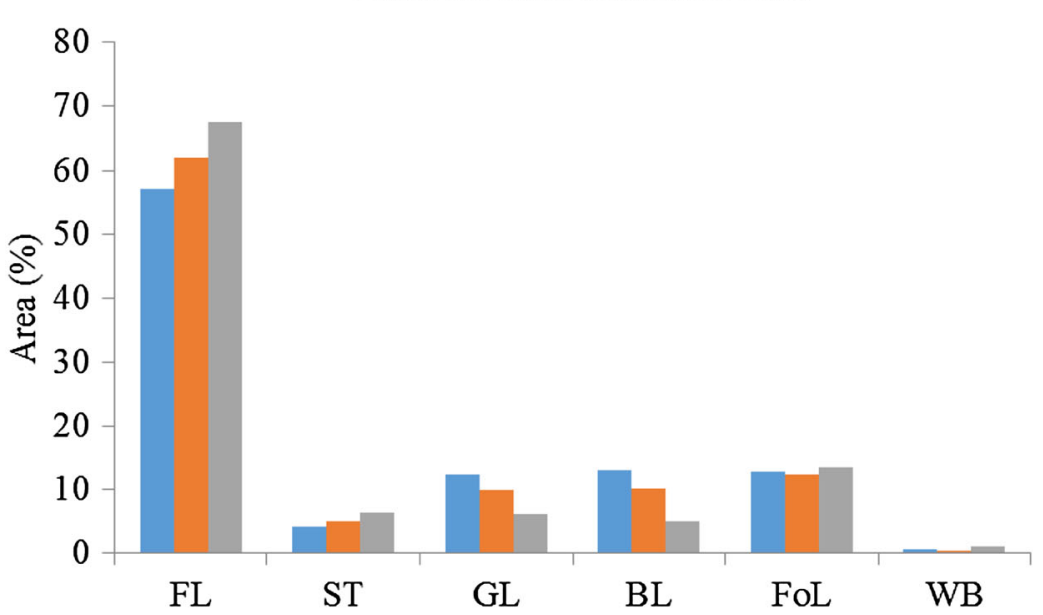

1984

- 1999

2015
- 1984

- 1999

- 2015

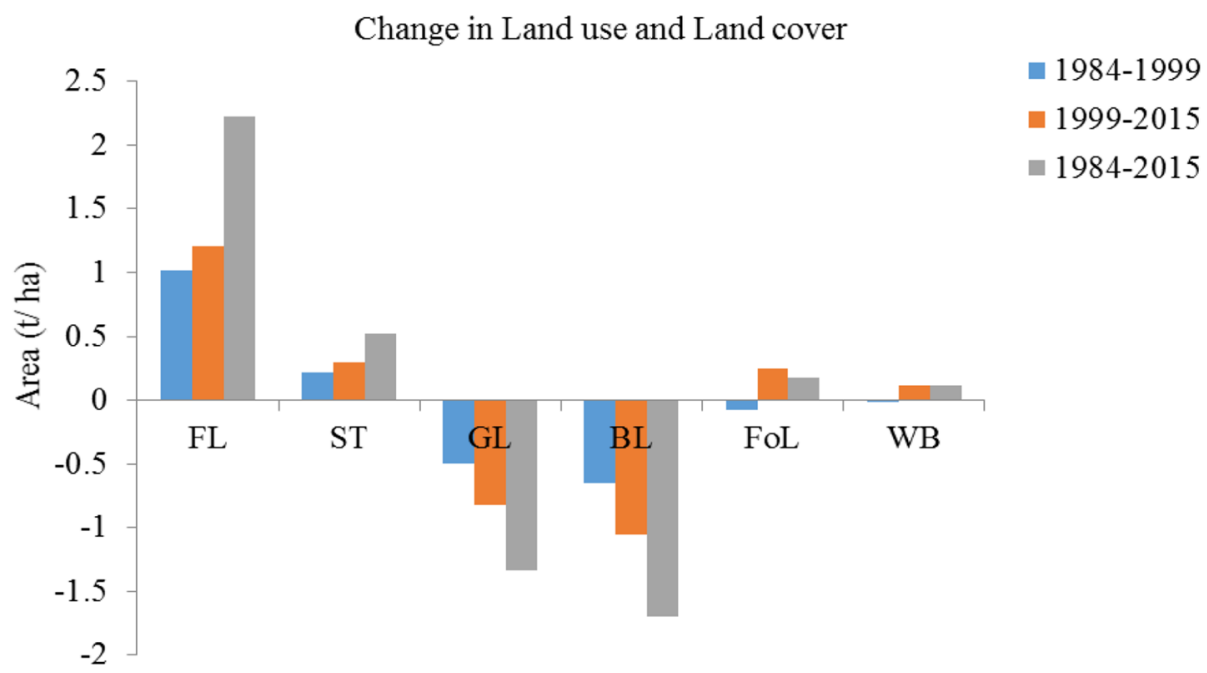

Water bodies Water bodies include ponds, springs, streams, and rivers. In the study area water bodies covered only $0.56 \%$, in 1984 and decreased to $0.5 \%$ but increased to $1.1 \%$ in 2015 (Figs. 3a, b, c, 4, 5, 6, 7; Table 3). The possible explanation of this fluctuation water bodies in the first periods (1984-1999 decreased by $0.3 \%$ ) is due to 
Fig. 7 Percentage change of Land use land cover class of the study watershed from 1984 to 2015

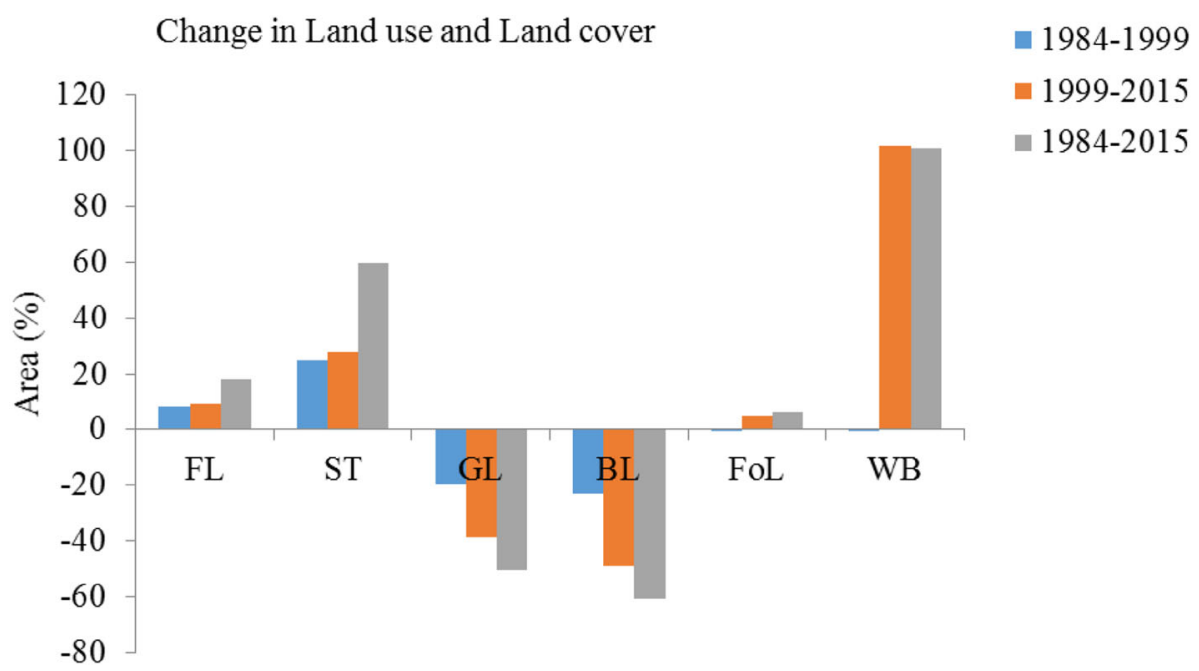

Table 3 Land use land and cover change of Beressa Watershed during 1984-2015

\begin{tabular}{|c|c|c|c|c|c|c|c|c|c|c|c|c|}
\hline \multirow[t]{3}{*}{ LULC classes } & \multicolumn{6}{|c|}{ Land use land cover area (ha) and \% share } & \multicolumn{6}{|c|}{ Change in land use land cover (ha) and \% share } \\
\hline & \multicolumn{2}{|l|}{1984} & \multicolumn{2}{|l|}{1999} & \multicolumn{2}{|l|}{2015} & \multicolumn{2}{|c|}{ 1984-1999 } & \multicolumn{2}{|l|}{ 1999-2015 } & \multicolumn{2}{|c|}{ 1984-2015 } \\
\hline & Area $(\mathrm{Ha})$ & $\%$ & Area (Ha) & $\%$ & Area $(\mathrm{Ha})$ & $\%$ & Area(ha) & $\%$ & Area (ha) & $\%$ & Area (ha) & $\%$ \\
\hline Farm land & 12179.3 & 57.1 & 13192.2 & 61.9 & 14400 & 67.5 & +1012.9 & +8.3 & +1207.8 & +9.2 & +2220.7 & +18.2 \\
\hline Settlement & 871.6 & 4.1 & 1089.4 & 5.1 & 1392.1 & 6.5 & +217.8 & +24.9 & +302.7 & +28 & +520.5 & +59.7 \\
\hline Grazing land & 2633.2 & 12.4 & 2123 & 10 & 1300 & 6.1 & -500.2 & -19.4 & -823 & -38.7 & -1333.2 & -50.6 \\
\hline Barren land & 2800 & 13.1 & 2152.7 & 10.1 & 1100 & 5.2 & -647.2 & -23.1 & -1052.8 & -48.9 & -1700 & -60.7 \\
\hline Forest land & 2722.8 & 12.8 & 2650 & 12.4 & 2900 & 13.6 & -72.8 & -0.3 & +250 & +4.7 & +177.2 & +6.5 \\
\hline Water body & 113.8 & 0.56 & 113.4 & 0.5 & 228.6 & 1.1 & -0.4 & -0.3 & +115.2 & +101.6 & +115 & +101 \\
\hline Total & 21320.7 & 100 & 21320.7 & 100 & 21320.7 & 100 & - & - & - & - & - & - \\
\hline
\end{tabular}

decrease rainfall pattern in the area. Likewise, the water harvesting habit of local farmers was low. But in the second periods (1999-2015) the availability of ponds and springs was persistently increased by $101.6 \%$. In the study periods for the last 31 years it has increased by $101 \%$.

\section{Rate of land use and land cover change dynamics}

The rate of changes of farm land, grazing land, forest land, water body barren land and settlement area cover for the study watershed have already been presented in Table 2 . This result indicated that though resource is fixed, there was various rate of change in different land cover types. However, the rate of change of different land cover types has slightly variables among them.

The analysis indicated that between 1984 and 1999, farm land and settlement area has increased with the rate of $67.5 \mathrm{ha} /$ year and $14.5 \mathrm{ha} /$ year respectively caused for the outflow of grazing land, barren land and forest land; in the same periods grazing land, barren land, forest land and water body was decreased by 33.3 ha/year, 43.1 ha/year, 5 ha/year, and 0.03 ha/year respectively. Likewise, between 1999 and 2015 expansion of farm land and settlement persistently increased with a rate of 75.5 and $18.9 \mathrm{ha} / \mathrm{annum}$. Unlike in the first periods, unexpectedly with increasing rate of settlement and farm land between 1999 and 2015 forest land and water body was increased by 15.6 and $7.1 \mathrm{ha} /$ year. In the second periods of study years between 1999 and 2015 the share of forest coverage surprisingly increased which was attributable to household and community level afforestation and reforestation practice, the government of Ethiopia in collaboration with donor organization and mobilized the community to attention for indigenous and multipurpose trees; beside this households were planting eucalyptus trees around homestead and farm land which is significantly contributed for the present extent of forest coverage of the study watershed. However, grazing and barren land rapidly decreased by with the rate of 51.4 and 65.8 ha/year in between 1999 and 2015. Over the last 31-year expansion farm field, settlement area, forest land and water body increased with a rate of $71.6,16.8,5.7$, and 3.7 ha/year contrary to this the share of grazing land and barren land shrunk with a rate of 43 and 54.8 ha/year respectively (Table 4). 
Table 4 Rate of change in LULC of Beressa Watershed

\begin{tabular}{lccc}
\hline LULC classes & \multicolumn{3}{l}{ Rate of change (ha/year) } \\
\cline { 2 - 4 } & $1984-1999$ & $1999-2015$ & $1984-2015$ \\
\hline Farm land & 67.5 & 75.5 & 71.6 \\
Settlement & 14.5 & 18.9 & 16.8 \\
Grazing land & -33.3 & -51.4 & -43 \\
Barren land & -43.1 & -65.8 & -54.8 \\
Forest land & -5 & 15.6 & 5.7 \\
Water body & -0.03 & 7.1 & 3.7 \\
\hline
\end{tabular}

The result of this finding particularly barren land different from a finding conducted by (Shiferaw 2011) indicated that in his study it has been increased by $256 \mathrm{ha} / \mathrm{year}$ between 1972 and 1985. Different study elsewhere made by Gashaw et al. (2014), and Dessie and Kleman (2007), indicated that the size of farm land and settlement area have been intensively expanded at the expense of forest cover, bare land and brazing land without significant conservation measure.

\section{Cause of land use and land cover change dynamics}

Even though the extent time periods of event occurrence are variables, various human and natural factors are the main cause for land use land cover dynamics (Meyer and Turner 1994). Though the effect of population growth rate on land cover dynamics is controversial, elsewhere in many literatures rapid rate of population growth rate one of the root cause for the change of land cover dynamics. According to (Barbier and Burgess 1996), instead of negatively affecting the study concluded that rapid population growth has positive role in availability of resource. On the contrary particularly in the highlands of Ethiopia in which population pressure is intense resulted for resource erosion and degradation (Grepperud 1996). Likewise, elsewhere in many part of Ethiopian high lands, pressure associated with populations has argued negative implication on forest land, grazing land, barren land, riparian vegetation and farm land (Tekle and Hedlund 2000). It is true to Beressa watershed where rapidly growing of population brought shortage of land, removal of forest cover and soil erosion and land degradation. However, local community were motivated with respect to afforestation practice consequently slow increase in forest coverage in the Beressa watershed. In addition, shortage of land resource forced them to cultivate gazing land, barren land and steep slopes land. Therefore, resource become more vulnerable for further erosion and degradation consequently shifted to other land use land cover class.

\section{Implication of land use and land cover change dynamics}

The change of land use and land cover class may not necessarily result in land degradation and soil erosion. However, if the change of land use land cover class is rapidly expanding into farm land, grazing land and barren land, fertile soil is more susceptible to massive erosion and degradation, particularly the land surface without dense forest (Tegene 2002; Maitima et al. 2009).

According to the classified image of change was detected in different land use class between 1984 and 2015 indicated that grazing land, barren land and forest land cover class were transferred into farm land and settlement area. This indicated that how land use and land cover class change over time accelerate erosion and degradation and associated consequence. The shift of other land use land cover class into farm land towards steep slope and barren land is the root cause for intensive erosion, massive degradation, siltation, water borne disseise, and flood.

Likewise, Tegene (2002) explained in his study rapid expansion of agricultural land into steeper slope has aggravated for erosion and degradation in Ethiopia. Similarly, Amede et al. (2001) illustrated destruction of vegetative cover because of expansion of farming practice into steeper slopes particularly in the highland of Ethiopia in which intensive farming practice undertaken without appropriate conservation practice is resulted for depletion of fertile soil. Expansions of farm land at the expense of grazing land resulted for insufficient availability of fodder for livestock and adversely affect the productivity livestock similarly, absence of animals for land preparation and transportation service. Likewise, due to the outflow of gazing land and forced farmers reducing livestock number consequently reduced availability of manure for soil fertility amendment and hence reduced in crop production.

According to Abbas et al. (2010), the change of land use land cover class significantly aggravated the surface runoff, soil erosion, land degradation, sedimentation, siltation, drought, migration, desertification loss of biodiversity, decrease in productivity and famine. In summary, the study has indicated the cause and consequence of land use land cover change with over all environment of the study watershed presented in Fig. 8.

\section{Conclusion}

In the last 31-years land use and land cover dynamics have undergone considerable change in the Beressa watershed. The land use and land cover dynamics observations showed the expansion of farm land and settlement land leading. On the contrary the grazing land and barren land declined. 


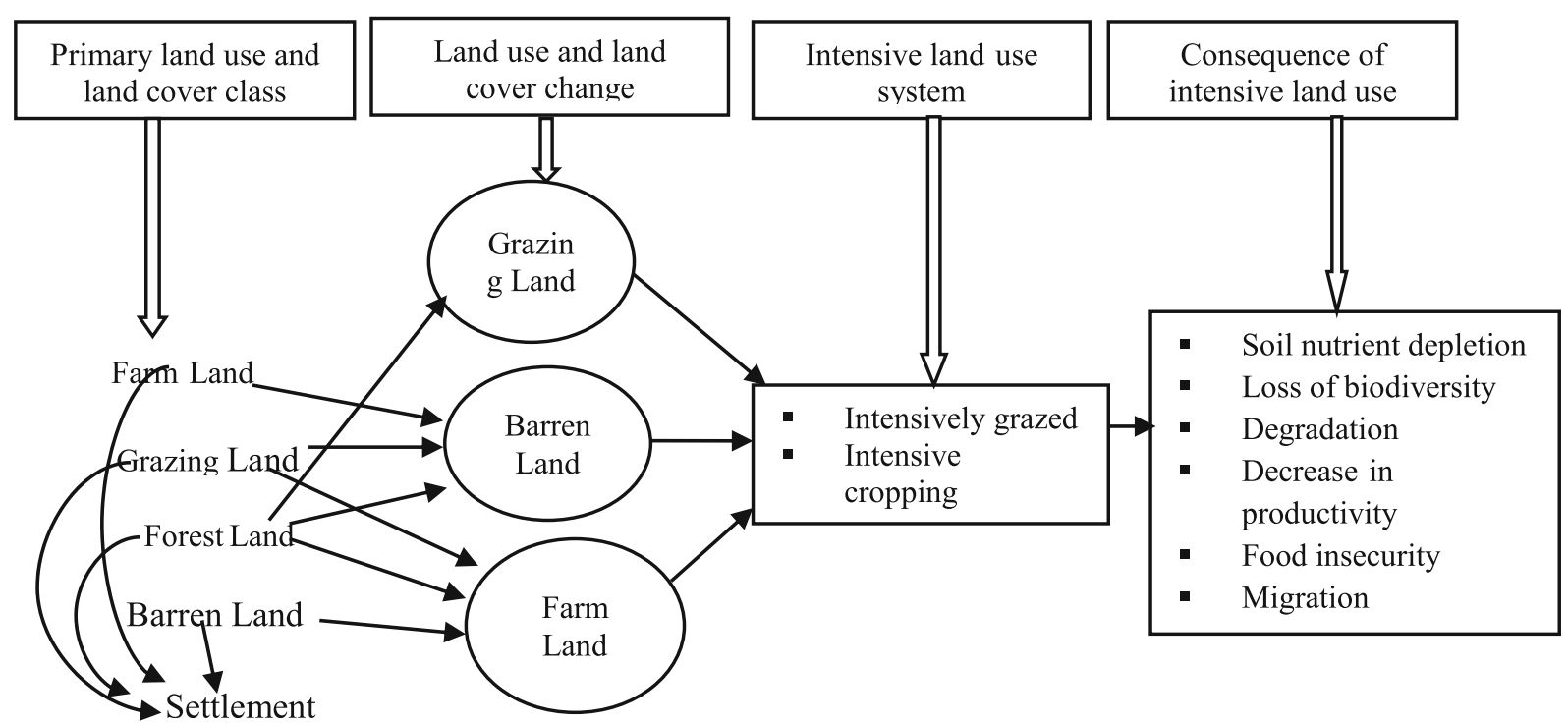

Fig. 8 Conceptual linkage of cause and consequence of land use land cover change of the watershed. Adopted from Maitima et al. (2009)

Contrary to the finding other studies elsewhere, Minale and Rao (2012a, b), Nurelegn and Amare 2014; Asres et al. (2016), even though farming and settlement was rapidly expanded, the trend of forest cover was increased. Increasing forest cover was possible due to the incentive provided by the government for community and household level indigenous tree plantations. The support of government and the efforts of communities are admirable because it is yielding a positive impact in preserving the ecology and the economic wellbeing of the community. The land use and land cover dynamics beyond onsite implications it has offsite environmental implication because massive soil erosion and land degradation has no limited boundaries.

The increasing forest cover is also affecting offsite environmental condition because massive soil erosion and land degradation has reduced. This could be possible due to proper integrated approach of upstream and downstream community under national and international support for environmental and ecological protection. Therefore, site specific community based awareness created about the appropriate use of available resources as well as the conservation and rehabilitation of environment proved to be very effective.

\section{Compliance with ethical standards}

Conflict interest The authors declared that they have no competing interests.

\section{References}

Abate S (2011) Evaluating the land use and land cover dynamics in Borena Woreda of South Wollo Highlands, Ethiopia. J Sustainable Dev Afr 13(1):1520-5509
Abbas II, Muazu KM, Ukoje JA (2010) Mapping land use-land cover and change detection in Kafur local government, Katsina, Nigeria (1995-2008) using remote sensing and GIS. Res J Environ Earth Sci 2(1):6-12

Amare S (2013) Population and environment interaction: the case of gilgel abbay catchment, North Western Ethiopia. E3 J Environ Res Manag 4(1):153-162

Amede T, Belachew T, Geta E (2001) Reversing the degradation of arable land in the Ethiopian Highlands, vol 23. IIED

Asres RS, Tilahun SA, Ayele GT, Melesse AM (2016) Analyses of land use/land cover change dynamics in the upland watersheds of Upper Blue Nile Basin. In: Landscape dynamics, soils and hydrological processes in varied climates. Springer, Berlin, pp 73-91

Ayele GT, Demessie SS, Mengistu KT, Tilahun SA, Melesse AM (2016) Multitemporal land use/land cover change detection for the Batena Watershed, Rift Valley Lakes Basin, Ethiopia. In: Landscape dynamics, soils and hydrological processes in varied climates. Springer, Berlin, pp 51-72

Barbier EB, Burgess JC (1996) Economic analysis of deforestation in Mexico. Environ Dev Econ 1(2):203-239

Baulies X, Szejwach G (eds) (1998) LUCC data requirements workshop: survey of needs, gaps and priorities on data for landuse/land-cover change research, Barcelona, 11-14 Nov 1997. Institut Cartogràfic de Catalunya

Carlson TN, Sanchez-Azofeifa GA (1999) Satellite remote sensing of land use changes in and around San Jose, Costa Rica. Remote Sens Environ 70(3):247-256

Clevers J, Bartholomeus H, Mücher S, De Wit A (2004) Land cover classification with the medium resolution imaging spectrometer (MERIS). EARSeL eProc 3(3):354-362

Dessie G, Kleman J (2007) Pattern and magnitude of deforestation in the South Central Rift Valley Region of Ethiopia. Mt Res Dev 27(2):162-168

Dezso Z, Bartholy J, Pongracz R, Barcza Z (2005) Analysis of landuse/land-cover change in the Carpathian region based on remote sensing techniques. Phys Chem Earth, Parts A/B/C 30(1):109-115

FAO (2004) Methodological framework for land degradation assessment in dry lands (LADA). Food and Agriculture Organization (FAO), Rome. In: Asres RS, Tilahun SA, Ayele GT, Melesse 
AM (2016) Analyses of land use/land cover change dynamics in the upland watersheds of Upper Blue Nile Basin. In: Landscape dynamics, soils and hydrological processes in varied climates (pp 73-91). Springer, Berlin

Fasona MJ, Omojola AS (2005) Climate change, human security and communal clashes in Nigeria. In: Human security and climate change conference

Gashaw T, Bantider A, Mahari A (2014) Evaluations of land use/land cover changes and land degradation in Dera District, Ethiopia: GIS and remote sensing based analysis. Int J Sci Res Environ Sci 2(6): 199

Goldewijk KK, Ramankutty N (2004) Land cover change over the last three centuries due to human activities: the availability of new global data sets. GeoJournal 61(4):335-344

Grepperud S (1996) Population pressure and land degradation: the case of Ethiopia. J Environ Econ Manag 30(1):18-33

Guerschman JP, Paruelo JM, Bella CD, Giallorenzi MC, Pacin F (2003) Land cover classification in the argentine pampas using multi-temporal landsat $\mathrm{TM}$ data. Int $\mathrm{J}$ Remote Sens 24(17):3381-3402

Lambin EF, Geist HJ, Lepers E (2003) Dynamics of land-use and land-cover change in tropical regions. Annu Rev Environ Res 28(1):205-241

Liang S, Fang H, Morisette JT, Chen M, Shuey CJ, Walthall CL, Daughtry CS (2002) Atmospheric correction of landsat ETM+ land surface imagery. II. Validation and applications. IEEE Trans Geosci Remote Sens 40(12):2736-2746

Lupo F, Reginster I, Lambin EF (2001) Monitoring land-cover changes in West Africa with SPOT vegetation: impact of natural disasters in 1998-1999. Int J Remote Sens 22(13):2633-2639

Maitima JM, Mugatha SM, Reid RS, Gachimbi LN, Majule A, Lyaruu H, Pomery D, Mathai S, Mugisha S (2009) The linkages between land use change, land degradation and biodiversity across East Africa. Afr J Environ Sci Technol 3(10):310-325

Mather AS, Needle CL (2000) The relationships of population and forest trends. Geogr J 166(1):2-13

Mendoza M, Bocco G, Bravo M (2002) Spatial prediction in hydrology: status and implications in the estimation of hydrological processes for applied research. Prog Phys Geogr 26(3):319-338

Meyer WB, Turner BL (1992) Human population growth and global land-use/cover change. Ann Rev Ecol Syst 23:39-61

Meyer WB, Turner II BL (1994) Changes in land use and land cover: a global perspective, vo 4. Cambridge University Press, Cambridge

Minale AS (2013) Retrospective analysis of land cover and use dynamics in Gilgel Abbay Watershed by using GIS and remote sensing techniques, Northwestern Ethiopia. Int $\mathrm{J}$ Geosci 4(07): 1003

Minale AS, Rao KK (2011) Hydrological dynamics and human impact on ecosystems of Lake Tana, northwestern Ethiopia. Ethiop J Environ Stud Manag 4(1)

Minale AS, Rao KK (2012a) Impacts of land cover/use dynamics of Gilgel Abbay catchment of Lake Tana on climate variability, Northwestern Ethiopia. Appl Geomat 4(3):155-162

Minale AS, Rao KK (2012b) Impacts of land cover/use dynamics of Gilgel Abbay catchment of Lake Tana on climate variability, Northwestern Ethiopia. Appl Geomat 4(3):155-162

Nurelegn M, Amare S (2014) Land use/cover dynamics in Ribb watershed, North Western, Ethiopia. J Nat Sci 4(16):9-16

Prakasam C (2010) Land use and land cover change detection through remote sensing approach: a case study of Kodaikanal taluk, Tamil nadu. Int J Geomat Geosci 1(2):150

Quentin FB, Jim C, Julia C, Carole H, Andrew S (2006) Drivers of land use change, final report: matching opportunities to motivations, ESAI project 05116, Department of Sustainability and Environment and primary industries, Royal Melbourne Institute of Technology

Reid RS, Kruska RL, Muthui N, Taye A, Wotton S, Wilson CJ, Mulatu W (2000) Land-use and land-cover dynamics in response to changes in climatic, biological and socio-political forces: the case of southwestern Ethiopia. Landsc Ecol 15(4):339-355

Shiferaw A (2011) Evaluating the land use and land cover dynamics in Borena Woreda of South Wollo highlands, Ethiopia. J Sustain Dev Afr 13(1):87-107

Tegene B (2002) Land-cover/land-use changes in the derekolli catchment of the South Welo Zone of Amhara Region, Ethiopia. East Afr Soc Sci Res Rev 18(1):1-20

Tekle K, Hedlund L (2000) Land cover changes between 1958 and 1986 in Kalu District, southern Wello, Ethiopia. Mt Res Dev 20(1):42-51

Trotter CM (1998) Characterising the topographic effect at red wavelengths using juvenile conifer canopies. Int J Remote Sens 19(11):2215-2221

Turner BL (ed) (1990) The earth as transformed by human action: global and regional changes in the biosphere over the past 300 years. CUP Archive

Turner A (2009) Population priorities: the challenge of continued rapid population growth. Philos Trans R Soc Lond B: Biol Sci 364(1532):2977-2984

Yitaferu B (2007) Land degradation and options for sustainable land management in the Lake Tana Basin (LTB). Amhara region, Ethiopia 